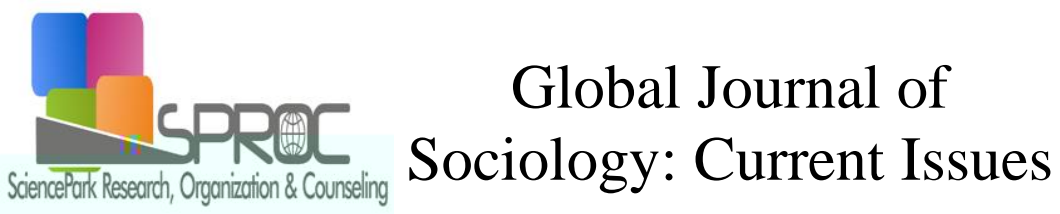

Volume 07, Issue 1, (2017)24-33

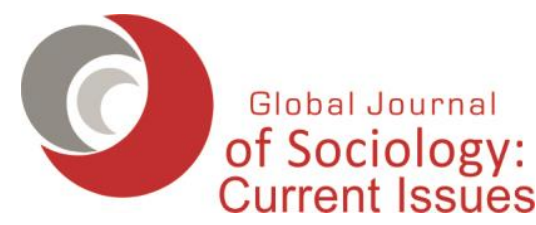

www.gjsoc.eu

\title{
Citizen satisfaction with municipal services: The case of Konya municipality
}

Erdal Bayrakci, Department of Political Sciences and Public Administration,Faculty of Social Sciences and Humanities, Necmettin Erbakan University, 42060, Selcuklu, Konya, Turkey

Erhan Orselli*, Department of Political Sciences and Public Administration,Faculty of Social Sciences and Humanities, Necmettin Erbakan University, 42060, Selcuklu, Konya, Turkey

Selcuk Kahraman, Department of Political Sciences and Public Administration,Faculty of Social Sciences and Humanities, Necmettin Erbakan University, 42060, Selcuklu, Konya, Turkey

\section{Suggested Citation:}

Orselli, E., Bayrakci, E. \& Kahraman S. (2017). C Citizen satisfaction with municipal services: The case of Konya municipality.

(1), 24-33.

Received November 20, 2016; revised January 11, 2017; accepted April 20, 2017.

Selection and peer review under re ponsibility of Mustafa Gunduz, Cukurova University, Turkey.

${ }^{\circ} 2017$ SciencePark Research, Organization \& Counseling. All rights reserved.

\begin{abstract}
Local governments, which are the closest units to people in terms of providing services, pay special attention to such issues as life and service quality, citizen satisfaction, meeting demands and expectations of citizens while making future plans and evaluating how successful they are in the public eye. The level of citizen satisfaction, citizens' experiences and perceptions about local services and their ideas about the legitimacy, credibility and performance of Mayor affect the success of local governments, particularly municipalities, in a positive or a negative way. This study aims to develop "a citizen report" about the local services in Konya by identifying how satisfied people are with the quality of the local public services provided by Konya Municipality.
\end{abstract}

Keywords: Local public services, service quality, citizen satisfaction, citizen report. 


\section{Introduction}

Demands and expectations of people from local governments have changed as a result of rapid developments in information and communication technologies, globalization and approaches like the new concept of public administration and citizen-centered governance. Today, public administrations and particularly local governments try to satisfy people by offering services compatible with their demands and expectations. In this context, acting according to demands of citizens and gaining their respect, support and appreciation have become more important issues for governments.

Together with the new understanding of public administration and citizen-oriented approach of administration, it has started to be discussed that the types of producing and providing services applied in private sector may also be applied in providing public service in public administration and local governments. In parallel with these developments, a structural transformation was started in public administration by abandoning old approaches in providing public services notably the statecitizen relationships. The understanding of be valid rather than the understanding of started to . Local governments have also had their shares of this change and transformation experienced. Provincial Special Administration and municipality laws, particularly Metropolitan Municipality included in the national legislation in Turkey have been changed and new regulations have been actualized in these fields. Basic laws regulating the units of local government have been reconsidered and the understanding of local government compliant with the current conditions, basing on contemporary management principles, placing importance on the participation of citizens and the principle of locality in providing public services, and emphasizing on the satisfaction and pleasure of citizens in the public services rendered was desired to be actualized. Hence, as it is specified in the general preamble of 5393 numbered Municipal Law, the necessity for

is emphasized.

Local governments and in particular municipalities must know and determine to what extent the citizens benefit from the public/local services rendered and the effects of those on life quality of the citizens to provide better services and expand the opportunities. Citizen carnets can be assessed as a tool of grading the quality of public services according to the information received from citizens and promoting fulfilling accountability of public in this manner. When the studies in the literature are analyzed, it is observed that the data used in citizen carnets are generally collected with household interview surveys. Citizen reports present systematic information about the performance of public service and the public institutions rendering these services by focusing on the conclusions (Vatandas Karnesi Rehberi, 2014).

This study aims to develop "a citizen report" about the local services in Konya by identifying how satisfied people are with the quality of the local public services provided by Konya Municipality. Accordingly, it seeks to answer the questions such as "

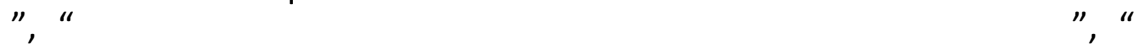

With this aim, a survey study has been planned and conducted to assess the level of citizen satisfaction with municipal public services. The survey has been supported by Necmettin Erbakan University Scientific Research Projects Coordination Unit. The study has been carried out within our project titled "

with the number "141221003". We have conducted face to face interviews with 1503 people in 111 neighborhoods and 13 districts in Konya between February 2016 and March 2016. The data gathered 
Orselli, E., Bayrakci, E. \& Kahraman S. (2017). C Citizen satisfaction with municipal services: The case of Konya municipality.

(1), 24-33.

by citizen surveys were analyzed to document the level of citizen satisfaction with municipal services in Konya.

\section{Quality in Local Services and Pleasure of the Citizens about Local Services}

The quality of the services provided by public enterprises has become quite important in terms of citizens in our day. The notion of globalization, the developments experienced in knowledge and communication technologies, downsizing of the state, new approaches and understandings in the field of public administration have significantly altered and increased the expectations of people from public. In this respect, from now on, citizens expect that public services must have the features required by nature of the era and quality (Ardic, Yuksel \& Cevik, 2004). In this sense, analysis of the factors affecting quality in the services provided by state and public enterprises ensures measurement of the quality of public services provided and understanding whether and to what extent citizens are satisfied with these factors (Ardic, Yuksel \& Cevik, 2004).

When evaluated in terms of local governments and particularly municipalities, quality can be defined as a constant function that penetrates into allover public services rendered by local government and coherence of the rendered services with fulfilling the expectations of the citizens (Peker, 1996). Necessity of local governments to provide quality services to the ones benefitting from the service has become almost an obligation in local public services in our day to gain and increase the support of the citizens to whom service is rendered (Azakli, 2000; Usta \& Memis, 2010). Furthermore, citizen-oriented administration approach requires that public administrations be sensitive to the desires and expectations of the citizens, form quality standards, and comply with these processes by designating works and procedures processes (Eryilmaz, 2008). Understanding of new administration ensuring that the relationships between state and citizens acquire a new dimension asserts that meeting the needs of the citizens will be carried out in different manners in local governments within the scope of being citizen-oriented (Kutlu, Usta \& Kocaoglu, 2009).

Local services are

. In this respect, local services are the local-joint services having a significant place in local people's maintaining their daily lives in terms of their characteristics such as

(Ozel, Eren \& Inal, 2009). Public enterprises plan to actualize the target of increasing the satisfaction of citizens while providing services to meet these needs happen in the society by means of municipalities. Therefore, municipalities bear tremendous responsibility regarding providing good quality service to the citizens and subsequently, increasing the satisfaction of the citizens. Ensuring the satisfaction of citizens is directly related to meeting the expectations and quality of the service. When this is provided, it is accepted that municipalities provide successful local service (Torlak, 1999). In other words, municipalities can fulfill their purpose of establishment and basic functions as long as they satisfy the desires and expectations of the citizens and increase the pleasure (Duman \& Yuksel, 2008; Dastan \& Delice, 2015).

The most suitable administration unit with which the satisfaction of the citizens from the performance of public services can be measured is local governments, municipalities. The reason for that is the smaller the activity area of the institutions providing public service, the easier to determine desires and expectations of the citizens and to increase the satisfaction (Eryilmaz, 2008). As it is specified in the general preamble of 5393 numbered Municipal Law, it is required to make the understanding basing on the demands of the citizens for providing compliance with law, efficiency and efficacy and for increasing the satisfaction of the ones benefitting from the services dominant in the administration in rendering local public services.

Acting sensitive to the wishes and expectations of the citizens to whom services are provided, and sustaining constant support, appreciation and trust of citizens are quite substantial for municipal administrations. The point to be paid attention is to measure to what extent the satisfaction of citizens 
are met in the performance of these services and actualization of providing citizen-oriented services by developing corrective-preventive activities (Henden \& Henden, 2005,; Gokus \& Alpturker, 2011). Within this context, it is required to determine and analyze the status of the citizens being the addressee of the services that is to say living in the district of the municipality and being satisfied or not satisfied with the services as an indicator of the quality in local services (Demirel, Yatkin, Dusukcan, Derin, Cakinberk \& Guven, 2013).

Researches on satisfaction are significant in terms of reflecting the change of paradigm in public administration and administration-citizen relationship. Aforementioned change is criticized in terms of defining the position of citizens before public services and public enterprises as customer. Besides this, its placing citizen and wishes, expectations and satisfactions of the citizens in the center of administration is found positive as it creates a means of oppression on public administration and especially on municipalities through satisfaction researches. Furthermore, several municipalities have started to carry out researches measuring the satisfaction of the citizens to whom they provide service in the recent times. In this regard, analyzing the results of the studies and rearranging the understanding of service and administration in this direction are assessed as a factor increasing the success of the municipal administrations and the satisfaction of citizens (Akyildiz, 2012).

Wishes and expectations of citizens from municipalities vary from citizen to citizen and time to time depending on economic and social reasons (Gokus \& Alpturker, 2011). The ones measuring the quality of the services rendered by municipalities, and in this direction the ones who are satisfied or not satisfied with the service are citizens who are the users of services. Besides this, it is also observed that the citizens are not always objective while evaluating the satisfaction of the citizens about the services provided. Some citizens pay attention to the way of providing service, but some form their sensation of satisfaction about the services rendered according to their previous experiences and expectations. Gender, previous experiences, occupation, status of income, culture, partisanship of political parties and suchlike factors are among the factors affecting satisfactions of the citizens about the services rendered by local governments and in particular municipalities and level of satisfaction of the citizens is determined according to these factors (Ardıc, Yuksel \& Cevik 2004; Ince \& Sahin, 2011; Sarıyer, 2008; Kurgun, Ozdemir, Kurgun \& Bakıcı , 2008; Usta \& Memis, 2010; Kara \& Gurcu, 2010; Gokus \& Alpturker, 2011; Akyıldız, 2012; Yucel, Yucel \& Atlı 2012; Mentese, 2013; Dastan \& Delice, 2015; Gurel \& Ozel, 2013; Orselli \& Bayrakcı, 2016).küçük ı'lar i olacak, Buyük I’ler I olacak.

\section{Aim and Methodology of the Research}

The service users of a municipality are the citizens that measure the quality of the services rendered by municipalities and in this direction the ones who are satisfied or not satisfied with the services. In the study; by determining and analyzing the quality of services provided in local level and level of satisfaction of the citizens in Konya; it is targeted to form a kind of " in local services that municipalities in Konya provide. Within this direction, the responses of the questions "

sought in the study. Within the direction of these objectives, the attitudes and opinions of the citizens living in Konya about local services are determined and the data acquired are analyzed correlating with one another.

In the present day, several national and international institutions or private researchers conduct various survey studies to examine and evaluate social events. The type of subjective criterion most frequently used in the studies carried out by using survey method is the indicators based on perception and experience. The method most frequently used in Turkey is also survey method (Orselli, 2016). When considered in this regard, there is great deal of survey studies directed on measuring the 
satisfaction of citizens about local services in the literature. As the level of satisfaction about local services was aimed to be measured over the perceptions of the citizens within the scope of this study, survey method was preferred.

Full-structured survey form was used as data collecting tool in the study. Survey study was conducted between in thirteen districts in the province of Konya within the direction of sampling plan designated. Nineteen surveyors and two site coordinators participated in survey study in total. After the application phase of survey study was completed, the data on the survey forms having consistent responses were coded and uploaded to SPSS 22.0 program and then phase of analysis was passed.

coefficient was calculated in the similar questions for researching the reliability of the scale used in the study and reliability of the scale was determined as, 831.

Geographical scope of survey study covers all residential areas within the borders of province of Konya. The universe of the research is comprised of citizens of Turkish Republic living within the borders of the province of Konya and over 18 years old. Survey study was carried out with face to face meeting method with 1503 participants in total in thirteen districts and one hundred and eleven neighborhoods in Konya.

How many surveys would be conducted in which districts in Konya was determined by layering the number of electors in The neighborhoods determined in as per the density of population of 2015 Address-Based Population Registration System in districts were selected as samples. After the determination of accommodation units, streets or avenues that the survey will be applied in the determined neighborhoods were selected randomly. Probability sampling was not preferred in the determination of the participants to be interviewed and gender and age quotas were applied.

\section{Analysis and Findings of Survey Study}

In this section of the study, the findings of survey study conducted to determinate and analyze the level of satisfaction of the citizens from local services are included.

The first question asked with the purpose of determination of socio-demographic features of the sample who participated in the study was directed to determine the gender distribution of the participants. When the age distribution of the participants were examined, it was observed that $49,2 \%$ was "female"; and 50,8\% was "male". When the participants were examined in terms of gender, it can be said that it reflected the universe of Konya with a slight difference compared to gender data of 2015 Address-Based Population Registration System.

When ages of the participants were examined, it was observed that $17,1 \%$ is between $18-24 ; 25 \%$ was between $25-34 ; 23 \%$ was between $35-44 ; 15,9 \%$ was between $45-54 ; 19 \%$ was 55 and older. It can be said that sample had a young profile.

When the features of the participants concerning marital status were analyzed, it was determined that $74,4 \%$ was married, $22 \%$ i was single, and $1,6 \%$ was divorced. When the participants are examined in terms of marital status, it can be said that the direction of the distribution is on "married". 
When educational background of the participants were examined, it was observed that $3,7 \%$ was "literate", 44,2\% was "primary school graduate", 13,4\% was "elementary school graduate", 22,2\% was "high school graduate", 14,8\% was "university graduate", and 1,2\% "postgraduate".

When distribution of the participants by occupation groups were examined, it was observed that 36,7was "housewife"; 15,7\% was "small business owner/handicraftsmen"; 11,2\% was "worker"; $10,8 \%$ was "student"; $10,4 \%$ was "retired"; $2,9 \%$ "private sector staff"; $2,2 \%$ "self-employed"; $1,9 \%$ "state official"; 1,9\% was "unemployed"; 1,8\% "teacher/academic member"; 1,6\% "farmeragriculturist-husbandry"; $0,9 \%$ was "mid-level/senior executive in private sector"; 1,9\% was "merchant/businessman/industrialist".

When participants were examined in terms of income status, participants specified that $56,6 \%$ had income $2000 \mathrm{TL}$ and lower, 37,1\% between 2001-4000 TL, 3,9\% between 4001-6000 TL, 1,7\% $6001 \mathrm{TL}$ and more. According to the findings obtained, majority of the participants had $2000 \mathrm{TL}$ and lower income.

Some sets of hypothesis were presented to the participants to learn their thoughts about Konya and to what extent they were satisfied with living in Konya and they were asked whether they agreed on these hypotheses. The findings acquired are given in Table1.

Table1. Perceptions of the Participants concerning living in Konya

\begin{tabular}{lll}
\hline Living in Konya & Average & Level of agreement \\
\hline Konya is an ideal city to raise children & 4,20 & 84,0 \\
Konya is a livable city & 4,14 & 82,9 \\
Konya is a good place to spend old age & 4,07 & 81,4 \\
I feel myself secure in Konya & 4,12 & 82,3 \\
I am pleased with living in Konya & 4,13 & 82,6 \\
Konya is a comfortable city for transportation to other cities & 4,19 & 83,7 \\
\hline
\end{tabular}

Note: (i) while averaging in the scale; totally agree is 5 , agree 4, neither agree nor disagree is 3 , disagree is 2 and totally disagree is 1 . The ones saying no idea were not included in the averaging.

When the findings obtained were examined, it was observed that participants most frequently agreed related to living in Konya with hypothesis. With a slight difference, participants agreed with

and

hypothesis substantially. When the findings were evaluated in this respect, it was observed that great majority of the participants were pleased with living in Konya.

As a result of the statistical analysis carried out with the purpose of determining whether sociodemographic features of the participants affect the perception of living in Konya; it was determined that there was not any relation between the genders of the participants and their perception of living in Konya; in other words, both men and women had the same level of pleasure about living in Konya. It was detected that the perception of living in Konya varied according to the age distribution of participants, 45 years and older were more pleased compared to youngers; and the higher their educational background was, the less pleasure they had with living in Konya. 
The question of

was asked to the participants for the determination of the problems deemed important in Konya and it was specified that they marked three options at the most. The responses are arranged in Table 2.

Table 2. Most Significant Problems of Konya

\begin{tabular}{llll}
\hline Responses & $\mathrm{F}$ & \% in Responses & \% in Participants \\
\hline Traffic-Transportation & 430 & 14,3 & 28,6 \\
Immigrants/Syrians & 382 & 12,7 & 25,4 \\
Unemployment & 381 & 12,6 & 25,3 \\
There is no problem & 298 & 9,9 & 19,8 \\
Financial difficulty & 215 & 7,1 & 14,3 \\
Road pavement maintenance and repair & 180 & 6,0 & 12,0 \\
Carpark & 145 & 4,8 & 9,6 \\
Air pollution & 109 & 3,6 & 7,3 \\
Education & 102 & 3,4 & 6,8 \\
Garbage and cleaning services & 97 & 3,2 & 6,5 \\
Rarity in social/cultural activities & 91 & 3,0 & 6,1 \\
Park and gardens & 86 & 2,9 & 5,7 \\
Security & 77 & 2,6 & 5,1 \\
Infrastructure-sewage & 74 & 2,5 & 4,9 \\
Lack of social facilities & 64 & 2,1 & 4,3 \\
Natural gas & 46 & 1,5 & 3,1 \\
Noise & 45 & 1,5 & 3,0 \\
Zoning-housing & 42 & 1,4 & 2,8 \\
Urban transformation & 31 & 1,0 & 2,1 \\
Lack of health services & 27 & 0,9 & 1,8 \\
Electricity problem & 25 & 0,8 & 1,7 \\
Water problem & 23 & 0,8 & 1,5 \\
Other & 5 & 0,2 & 0,3 \\
No response & 39 & 1,3 & 2,6 \\
Total & 3014 & 100,0 & 200,5 \\
\hline
\end{tabular}

Note: More than one response was received in this question and the percentage in participants was calculated on 1503 people.

According to the findings acquired, $28,6 \%$ of participants saw as the most important problem of Konya. The issue perceived as the second important problem $(25,4 \%)$ was ; and third important problem (25,3\%) was

participants saw

$$
\text { , 9,6\% saw }
$$

as most important problem, $12 \%$ saw , and $7,3 \%$ saw

of Konya. The rate of the ones who stated that there is no problem $(19,8 \%)$ was considerably high.

In the analysis carried out to see whether there was any difference according to gender regarding the problems perceived as most important in Konya, it was found that men considered more problematic than women did, and

were more specified by women compared to men. It was determined that the issues deemed as problem varied as per the age distribution of the participants; it was determined that the participants of 18-24 ages expressed

the less important was

more compared to other participants. Furthermore, the older the participants were, 
participants were, the more important problem was

as problem for them. Besides this, the older the background of the participants.

for them. There was not any meaningful difference in the perception by educational

The question

was asked to the participants to determine how much the participants were satisfied with the services provided in local level and the findings are arranged in Table 3.

Table 3. Satisfaction about Local Services

\begin{tabular}{lll}
\hline Local services & Average & Satisfaction Level \\
\hline 112 Emergency Health/Ambulance Services & 4,11 & 82,2 \\
155 Police Emergency Services & 4,11 & 82,2 \\
Fire Brigade Services & 4,07 & 81,5 \\
KOMEK Courses & 4,07 & 81,4 \\
Cemetery and Funeral Services & 4,04 & 80,8 \\
Civil Registry and Citizenship Services & 3,90 & 78,1 \\
Education in State Schools & 3,88 & 77,6 \\
Public Security Services & 3,88 & 77,5 \\
Security and Public Order & 3,86 & 77,1 \\
Title Deed Services & 3,82 & 76,5 \\
Urban Transformation Works & 3,82 & 76,4 \\
Zoning-Housing, License Services & 3,82 & 76,3 \\
Social Services directed to Women & 3,81 & 76,3 \\
Social Insurance and Retirement Services & 3,81 & 76,3 \\
Elders-Oriented Services & 3,78 & 75,6 \\
Mukhtar Services & 3,77 & 75,5 \\
Museums & 3,77 & 75,5 \\
Services Oriented to Children & 3,76 & 75,1 \\
Social Aids & 3,74 & 74,8 \\
Services Oriented to Disables & 3,73 & 74,6 \\
Artistic and Cultural Services (concert-festivals) & 3,66 & 73,3 \\
Natural gasservise & 3,65 & 72,9 \\
Traffic Arrangement and Inspection Service & 3,64 & 72,7 \\
Services directed to youths & 3,62 & 72,4 \\
\hline
\end{tabular}

Note: (i) Totally not happy is 1 ; not happy is 2 ; neither happy nor unhappy is 3 ; happy is 4; quite happy is 5 in the scale.

When the findings obtained were analyzed, the locally provided service that participants were mostly satisfied with was

was in the second; and

was in the third rank. Three services that were least satisfied with were

. When the satisfaction averages of the services sharing the last three ranks were analyzed, it was observed that actually these were services that people were usually satisfied with at quite high level in Konya-wide. However, it can be said that they received fewer points in the ranking compared to other local services. 
As a result of the statistical analysis carried out with the purpose of determining whether gender affected the satisfaction of the participants about local services; it was observed that the level of satisfaction about some local services varied according to genders of the participants. According to the findings, women were more satisfied with

compared to men. Furthermore, the older the participants were; the higher level of satisfaction they had with the services relatively; besides this, the higher educational background the participants had, the less satisfied they were with the services.

\section{Conclusion}

It was determined that the participants mostly agreed with hypothesis related to living in Konya; the second mostly agreed item was and third one was

. When the findings were evaluated in general, it was concluded that majority of the participants were pleased to live in Konya. In the analysis carried out to determine whether the thoughts of the participants about living in Konya varied as per the districts they live or not; it was found out that the district with the highest level of satisfaction was Meram District. It was also found that that gender of the participants did not change their perception about living in Konya; besides this, the perceptions of the participants varied as per the age distributions, 45 years and older are more pleased compared to younger ones; and the participants with higher educational background had less pleasure of living in Konya than the others.

When the most important problems of Konya perceived by the participants were analyzed, was in the first rank, was in second rank; and

was in the third. However, the rate of those who stated that there was no problem $(19,8 \%)$ was a considerably high. It was found out that there were some differences among the most important problem perceptions of the participants according to their socio-demographic features. Not any meaningful difference could be found between the level of education of participants and their perception of problems.

It was detected that level of satisfaction of participants about local services throughout Konya was $76,8 \%$ and in this respect, local services in Konya were satisfied with at quite high rates. As per the findings acquired; the locally provided service that participants were mostly satisfied with was was in the second; and was in the third rank. Three services that were least satisfied with were

. When the satisfaction averages of the services sharing the last three ranks were analyzed, it was observed that actually these are services that are satisfied with at quite high level in Konya-wide. Furthermore, it was determined that there was a meaningful difference between the age distributions of the participants and satisfaction level of them about local services; the older the participants were, the higher level of satisfaction they had with the services relatively; and the higher educational background the participants had, the less satisfied they were with the services; and there was also a meaningful difference between the satisfaction levels of the participants about local services as per their political party partisanship.

According to the result of this study conducted with the aim of determining and analyzing the satisfaction of citizens about local services in Konya; it was concluded that citizens were in general terms satisfied with local-public services to a large extent. It was detected that socio-demographic features of citizens affected satisfaction level in some service kinds and it was observed that these findings of the study were in parallel with the results of similar studies conducted in the literature. 


\section{References}

Akyıldız, F. (2012). Belediye Hizmetleri ve Vatandas Memnuniyeti: Usak Belediyesi Ornegi. , 4415-4436.

Ardıc, K., Yuksel, F., \& Cevik, O. (2004). Belediyelerde Hizmet Kalitesinin (Vatandas Tatmininin) Olculmesi: Tokat Belediyesinde Bir Uygulama. , 63-81.

Azaklı, S. (2000). Belediyelerin Hizmet Stratejileri Belirleme Surecinde Analizci Yaklasimin Onemi. , 413-436.

Dastan, I., \& Delice, M.E. (2015). Belediye Hizmetlerinden Memnuniyet Duzeylerini Etkileyen Faktorlerin Degerlendirilmesi: Izmir Buyuksehir Belediyesi Ornegi,

$$
\text { 203-223. }
$$

Demirel, E., Yatkin, A., Dusukcan, M., Derin, N., Cakinberk, A., \& Guven, M. (2013). Secmen Goruslerine Gore Belediye Hizmet Kalitesi. , 31-52.

Duman, T., \& Yuksel, F. (2008). Belediyelerde Vatandas Memnuniyetinin Olcumu: Mersin Buyuksehir Belediyesi Ornegi.

Eryılmaz, B. (2008). , , 43-57.

Gokus, M., \& Alpturker, H. (2011). Belediyelerin Sundugu Hizmetlerde Vatandas Memnuniyeti: Silifke Belediyesi Ornegi. , , 121-133.

Gurel, B., \& Ozel, C. (2013). Kamu Calisanlarinin Buyuksehir Belediye Hizmetlerinden Memnuniyeti: Ankara Ornegi. 65-74.

Henden, B., \& Henden R. (2005). Yerel Yonetimlerin Hizmet Sunumlarındaki Degisim ve E-belediyecilik. , , 48-66.

Ince, M., \& Sahin, K. (2011). Belediye Hizmetlerinde Vatandas Memnuniyeti Olcumu: Selcuklu Belediyesi Ornegi.

Kara, M., \& Gurcu, M. (2010). Belediye Hizmetlerinde Halkin Memnuniyetinin Olculmesine Yonelik Bir Calisma: Yozgat Belediyesi Ornegi. , 79-86.

Kurgun, A., Ozdemir, A., Kurgun, H. \& Bakıcı, Z. (2008). Belediyelerde Hizmet Yeterliliginin ve Hizmet Kalitesinin Artirilmasini Etkileyen Faktorlerin Analizi: Izmir Karsiyaka Belediyesinde Uygulama.

$$
\text { , 29-54. }
$$

Kutlu, O., Usta, S., \& Kocaoglu, M. (2009). Vatandas Odaklı/Vatandasın Odakta Oldugu Yonetim: Kent Konseyleri ve Selcuklu Belediyesi Ornegi. 532.

Mentese, S. (2013). Halkın Belediye Hizmetlerinden Memnuniyet Duzeyinin Tunceli Belediyesi Yonunden Degerlendirmesi. 831-862.

Orselli E., \& Bayrakcı E. (2016).

Orselli, E. (2016).

. Konya: Cizgi Kitabevi.

Konya: Cizgi Kitabevi.

Ozel, M., Eren, V., \& İnal, M. E. (2009). Yerel Siyaset ve Yerel Halkin Belediye Hizmetlerine BakısI: Yerel Hizmetlerden Memnuniyet Duzeyi Uzerine Bir Arastirma.

Peker, O. (1996). Belediye Yonetimlerinde Kalite Uretimi. $\quad$ 15-23.

Sarıyer, N. (2008). Gloval Olcegi ile Belediye Hizmetlerinde Musterinin Algıladıgı Degerinin Belirlenmesi-Kayseri Buyuksehir Ornegi. (3), 163-185.

Torlak, O. (1999). Belediye Hizmetlerinde Pazarlama. $\quad$ 96-114.

Usta, R., \& Memis, L. (2010). Belediye Hizmetlerinde Kalite: Giresun Belediyesi Ornegi. 333-355.

Vatandas Karnesi Rehberi (2014). , Icisleri Bakanligi Mahalli Idareler Genel Mudurlugu.

Yucel, N., Yucel, A., \& Atlı, Y. (2012). Belediyelerin Sundugu Hizmetlerde Vatandas Memnuniyeti: Elazig Belediyesi Ornegi. 